\title{
Kedudukan Hukum dan Keabsahan Kepemilikan Hak Atas Tanah Warga Negara Asing yang Berasal Dari Pewarisan
}

\author{
Muhammad Setya Ady Syarifuddin \\ Setyaadi10.sa@gmail.com \\ Universitas Airlangga
}

\begin{abstract}
There are several factors that can cause problems in the land sector in Indonesia, one of which is inheritance. This study aims to determine: 1) the legal position of the heirs of foreign citizens in the object of inheritance in the form of land rights obtained from inheritance with Indonesian citizenship; and 2) The validity of the control of land rights by foreign countries on objects originating from the inheritance of Indonesian citizens. The research method uses a normative juridical approach to the law (statute approach), conceptual approach (conceptual approach), and case study approach (case study). The results of the study are heirs who have changed their status to foreign citizens can also be proven by their lineage or have blood relations so that if they acquire property in the form of land originating from inheritance while those who control the property are foreign nationals, if possible, do so to discuss the object. through an exchange, grant, or auction within a maximum period of 1 (one) year, the status will automatically switch. If the land has been turned into state land, then the owner is considered to have relinquished his rights but the owner is still given the opportunity by law to be able to apply for the Right to Use the land.

Keywords: Inheritance Law; Legality Of Ownership Of Land Rights; Foreign Nationalilty.
\end{abstract}

\footnotetext{
Abstrak

Terdapat beberapa faktor yang dapat menimbulkan permasalahan di bidang pertanahan di Indonesia, salah satunya adalah pewarisan. Penelitian ini bertujuan untuk mengetahui: 1) Kedudukan hukum ahli waris warga negara asing dalam pewarisan obyek waris berupa hak atas tanah yang diperoleh dari pewarisan berkewarganegaraan Indonesia; dan 2) Keabsahan penguasaan Hak Atas Tanah yang dilakukan oleh warga negara asing atas obyek yang berasal dari Pewarisan berkewarganegaraan Indonesia. Metode penelitian menggunakan yuridis normatif dengan pendekatan perundang-undangan (statute approach), pendekatan konseptual (conceptual approach), dan pendekatan studi kasus (case study). Hasil penelitian yaitu ahli waris yang telah berubah status kewarganegaraan menjadi warga negara asing juga dapat menjadi ahli waris yang dibuktikan dengan adanya garis keturunan atau memiliki hubungan darah sehingga jika memperoleh harta berupa tanah yang berasal dari pewarisan sedangkan yang menguasai harta tersebut sudah menjadi warga negara asing maka sebaiknya dilakukan peralihan terhadap obyek tersebut melalui jual beli, tukar menukar, hibah, atau lelang dalam jangka waktu maksimal 1 (satu) tahun karena jika lebih dari jangka waktu tersebut maka status tanah akan beralih secara hukum menjadi tanah negara. Jika tanah tersebut telah beralih menjadi tanah negara maka si pemilik dianggap telah melepaskan haknya tetapi si pemilik masih diberi kesempatan oleh undang-undang untuk dapat mengajukan permohonan Hak Pakai atas tanah.

Kata Kunci: Hukum Waris; Keabsahan Kepemilikan Hak Atas Tanah; Warga Negara Asing. 


\section{Pendahuluan}

Tanahsebagai salah satu sumber daya agrariamempunyai peranyang sentral dalam kehidupan manusia, baik sebagai individu maupun dalam kehidupan berkelompok sebagai negara. ${ }^{1}$ Dalam kehidupan bernegara, perseorangan, dan masyarakat, tanah merupakan benda yang sangat dibutuhkan. Kebutuhan atas tanah ini meningkat sejalan dengan bertambahnya jumlah penduduk dan meningkatnya kebutuhan lain yang berkaitan dengan tanah. Tanah merupakan kebutuhan dasar umat manusia, karena manusia membutuhkannya sebagai tempat berpijak dan tempat untuk menjalani aktifitasnya. Aktifitas tersebut berfungsi untuk memberikan kesejahteraan hidup manusia yang dapat menunjang kehidupannya seperti membangun rumah untuk tempat tinggal, dan bercocok tanam. Akan tetapi selain kegunaan tersebut, tanah juga dapat dipergunakan sebagai jaminan mendapatkan pinjaman di Bank untuk keperluan jual beli, sewa menyewa.

Kepastian hukum mengenai hak-hak atas tanah sebagaimana yang di cita-citakan oleh Undang-Undang Nomor 5 Tahun 1960 Tentang Peraturan Dasar Pokok-Pokok Agraria (selanjutnya disebut dengan UUPA), mencakup tiga hal, yaitu kepastian mengenai obyek hak atas tanah; kepastian mengenai subyek hak atas tanah; dan kepastian mengenai status hak atas tanah. Khusus mengenai kepastian obyek hak atas tanah, secara teknis hal ini menuntut adanya sifat keunikan setiap bidang tanah yang bersangkutan. Keunikan inilah yang menghindarkan dari berbagai sengketa tanah yang bersumber pada sengketa batas dan letak bidang tanah. Oleh karena itu, kepastian mengenai obyek ini harus mampu menunjukkan secara jelas kepada semua pihak tentang batas, luas, dan letak dari bidang tanah yang bersangkutan. Untuk memberikan kepastian yang demikian diperlukan infrastruktur yang memadai sehingga bidang tanah yang ada di lapangan dapat digambarkan pada peta dan surat ukur secara benar. ${ }^{2}$

\footnotetext{
${ }^{1}$ Sri Hajati \& Agus Sekarmadji, Buku Ajar Politik Hukum Pertanahan (Pusat Penerbitan dan Percetakan UNAIR 2011).[258-259].

${ }^{2}$ Adrian Sutedi, Tinjauan Hukum Pertanahan (PT Pradnya Paramita 2009).[7].
} 
Ada beberapa faktor yang dapat menimbulkan permasalahan di bidang pertanahan di Indonesia, salah satunya adalah pewarisan dan mengenai pengaturan hak atas tanah waris di Indonesia yaitu berlakunya tiga hukum waris yaitu hukum waris adat, hukum waris islam dan hukum waris perdata. Berdasarkan Pasal 830 Kitab Undang-Undang Hukum Perdata / Burgerlijk Wetboek voor Indonesie (selanjutnya disebut dengan BW) dijelaskan bahwa pewarisan hanya berlangsung karena kematian dan juga dijelaskan di dalam pasal 832 BW bahwa yang berhak untuk menjadi ahli waris ialah para keluarga sedarah baik sah maupun luar kawin dan si suami atau istri yang hidup terlama.

Hukum waris adalah suatu rangkaian ketentuan-ketentuan, dimana, berhubungan dengan meninggalnya seorang, akibat-akibatnya di dalam bidang kebendaan, diatur, yakni: akibat dari beralihnya harta peninggalan dari seorang yang meninggal, kepada ahli waris, baik dalam hubungannya antara mereka sendiri, maupun dengan pihak ketiga. ${ }^{3}$ Waris timbul karena adanya peristiwa hukum kematian. Peristiwa kematian itu terjadi pada seorang anggota keluarga, misalnya, ayah, ibu, atau anak. Apabila orang yang meninggal itu memiliki harta kekayaan, maka yang menjadi persoalan bukanlah peristiwa kematian itu, melainkan harta kekayaan yang ditinggalkan. ${ }^{4}$ Dengan demikian, peristiwa hukum kematian seseorang akan mengakibatkan beralihnya segala hak dan kewajiban dari pewaris kepada ahli waris yang berhak, untuk menggantikan kedudukan dari pewaris. ${ }^{5}$ Oleh karena itu, terdapat sesuatu permasalahan hukum yang terjadi di dalam kehidupan masyarakat dan permasalahan hukum tersebut salah satunya berasal dari harta pewarisan.

Terkait hal tersebut di atas, salah satunya terjadi permasalahan di Desa Sidomukti, Kecamatan Jatirogo, Kabupaten Tuban, Provinsi Jawa Timur, dengan kronologis sebagai berikut:

1. Pada tahun 2013 terjadi kecelakaan yang mengakibatkan suami dan istri

${ }^{3}$ A. Pitlo, Perkembangan Hukum Waris Praktik Penyelesaian Sengketa Kewarisan Di Indonesia (Prenadamedia Grup 2019).[ 7].

${ }^{4} \mathrm{ibid}$.

${ }^{5}$ ibid. [8]. 
beragama islam dan keturunan bumi putera meninggal dunia meninggal dunia. Suami dan istri tersebut (disebut pewaris) beragama islam yang memiliki 4 (empat) orang anak (disebut ahli waris) dan memiliki harta berupa beberapa bidang tanah (disebut harta waris). Sehingga dengan adanya peristiwa kematian tersebut maka harta waris beralih dari pewaris kepada ahli waris dengan bagian masing-masing yang telah disepakati oleh ke-4 (empat) orang anak (ahli waris) tersebut.

2. Pada tahun 2014 harta waris berupa bidang tanah telah dibagikan sesuai kesepakatan antara ahli waris dan dilakukan balik nama menjadi nama masing-masing ahli waris.

3. Pada bulan Desember tahun 2020 salah satu dari ke-4 (empat) ahli waris tersebut menikah. Suami dari ahli waris bekerja di luar negeri dan menetap di sana. Berkaitan dengan hal tersebut, maka suami dan istri (ahli waris) tersebut berpindah kewarganegaraan Qatar, sehingga pada saat itu juga istri (ahli waris) berniat untuk menjual sebidang tanah yang diperoleh dari pewarisan.

Dari kronologis tersebut di atas maka diketahui adanya permasalahan hukum yang terjadi dalam proses pewarisan tersebut yaitu salah satu ahli waris telah berpindah menjadi warga negara asing sedangkan masih memiliki sebidang tanah yang diperoleh dari pewarisan. Jika merujuk pada Pasal 20 ayat (2) UUPA disebutkan sebagai berikut: "Hak milik dapat beralih dan dialihkan kepada pihak lain". Kemudian dilanjutkan pada Pasal 21 ayat (1) UUPA, dijelaskan bahwa hanya Warga Negara Indonesia dapat mempunyai hak milik. Kemudian dipertegas lagi pada Pasal 21 ayat (3) bahwa dengan diberlakukannya undang-undang ini, maka orang asing yang memperoleh hak milik karena pewarisan tanpa wasiat atau warga negara Indonesia yang beralih menjadi warga negara asing maka diwajibkan untuk melepaskan hak itu di dalam jangka waktu 1 (satu) tahun sejak diperolehnya hak tersebut atau hilangnya kewarganegaraan itu dan jika pada jangka waktu tersebut tidak segera dilepaskan maka hak tersebut hapus karena hukum dan tanahnya jatuh kepada Negara.

"Beralih" maksudnya terjadi bukan karena suatu perbuatan hukum (kesengajaan) melainkan karena peristiwa hukum (bukan kesengajaan), misalnya 
diwariskan. Sementara itu, "dialihkan" menunjukkan adanya kesengajaan sehingga terdapat suatu perbuatan hukum terhadap hak milik tersebut. ${ }^{6}$ Salah satu perbuatan hukum peralihan hak milik atas tanah ialah dengan jual beli tanah. Dalam kebiasaan praktik jual beli tanah pada saat ini diharapkan terdapat kepastian hukum yang dapat menjamin berlangsungnya kegiatan tersebut melalui balik nama sertitikat hak atas tanah. Peralihan hak milik atas tanah melalui jual beli hanya dapat didaftarkan jika dibuktikan dengan akta yang dibuat oleh Pejabat Pembuat Akta tanah (selanjutnya disebut sebagai PPAT) yang berwenang menurut ketentuan Peraturan Pemerintah Nomor 37 Tahun 1998 yang telah diubah dengan Peraturan Pemerintah Nomor 24 Tahun 2016 Tentang Peraturan Jabatan Penjabat Pembuat Akta Tanah. Akta PPAT ini dapat disebut sebagai akta autentik. Suatu akta autentik mempunyai kekuatan pembuktian yang sempurna bagi para pihak beserta seluruh ahli warisnya atau pihak lain yang mendapat hak dari para pihak. Sehingga apabila suatu pihak mengajukan suatu akta autentik, hakim harus menerimanya dan menganggap apa yang dituliskan di dalam akta itu sungguh-sungguh terjadi, sehingga hakim tidak boleh memerintahkan penambahan pembuktian lagi. ${ }^{7}$

Kepastian hukum terhadap obyek tanah ini juga harus menunjukkan secara jelas apakah seorang ahli waris yang berkewarganegaraan Indonesia dengan obyek tertentu misalnya tanah yang didapatkan melalui waris itu sah dan tetap dapat menjadi hak milik ketika seorang berkewarganegaraan Indonesia tersebut berpindah kewarganegaraan lain, apakah status sebagai ahli waris dapat dihapuskan dengan adanya perpindahan kewarganegaraan tersebut sesuai dengan peraturan perundang-undangan yang berlaku.

\section{Metode Penelitian}

Tipe penelitian yang digunakan dalam penelitian ini adalah penelitian yuridis normatif. Penelitian yurudis normatif adalah suatu metode penelitian

${ }^{6}$ John Salindeho, Masalah Tanda Dalam Pembangunan (Sinar Grafika 1987).[38].

${ }^{7}$ Oemar Moechthar, Dasar-Dasar Teknik Pembuatan Akta (Airlangga University Press 2017).[22]. 
ilmiah untuk menemukan kebenaran berdasarkan logika keilmuan hukum dari sisi normatifnya. ${ }^{8}$ Tipe penelitian hukum normatif, yang artinya penelitian berdasarkan suatu masalah dilihat dari aspek hukumnya berdasarkan bahan hukum primer dan bahan hukum sekunder yaitu yang berkaitan dengan hukum seperti buku-buku teks, jurnal hukum dan karya ilmiah.

Pendekatan yang digunakan adalah dengan menggunakan pendekatan perundang-undangan (statute approach), pendekatan konseptual (conceptual approach) dan studi kasus (case study). Suatu penelitian normatif tentu harus menggunakan pendekatan perundang-undangan, karena yang akan diteliti adalah berbagai aturan hukum yang menjadi fokus sekaligus tema sentral suatu penelitian.

\section{Kedudukan Hukum Ahli Waris Warga Negara Asing Dalam Pewarisan Obyek Waris Berupa Hak Atas Tanah yang Diperoleh Dari Pewaris Berkewarganegaraan Indonesia}

Ketika seseorang meninggal dunia, hal ini menimbulkan sebuah akibat hukum yaitu tentang bagaimana pengurusan dan kelanjutan hak-hak dan kewajiban bagi seseorang yang telah meninggal dunia. Penyelesaian hak-hak dan kewajiban sebagai akibat adanya peristiwa hukum karena meninggalnya seseorang diatur oleh Hukum Waris. Jadi Hukum Waris itu dapat dikatakan sebagai himpunan peraturan-peraturan hukum yang mengatur hak-hak dan kewajiban seseorang yang meninggal oleh ahli waris. Maka Ahli warislah yang berhak mengurusi hak-hak dan kewajiban seseorang yang meninggal yang telah meninggal dunia tersebut.

Sampai saat ini Indonesia belum mempunyai Hukum Waris Nasional, karena di Indonesia terdapat berbagai lapisan masyarakat Hukum Adat yang masingmasing mempunyai Hukum Waris Adat berlainan antara satu suku dengan suku lainnya. Saat ini di Indonesia masih berlaku Hukum Waris menurut penggolongan penduduk seperti yang diatur sejak masa Hindia Belanda dahulu, yaitu:

\footnotetext{
${ }^{8}$ Johny Ibrahim, Teori Dan Metodologi Penelitian Hukum Normatif (Bayumedia 2012).[57].
} 
1. Hukum Waris menurut Burgerlijk Wetboek (BW). Hukum waris Burgerlijk Wetboek (BW) diatur dalam buku II bab XII hingga bab XVIII Burgerlijk Wetboek (BW), yang berlaku bagi golongan Eropa termasuk golongan Timur asing Tionghoa dan golongan yang menundukkan diri pada hukum Eropa. ${ }^{9}$

2. Hukum Waris Islam. Hukum waris islam diatur dalam Instruksi Presiden Nomor 1 Tahun 1991 Tentang Kompilasi Hukum Islam (selanjutnya cukup disingkat KHI), berlaku bagi warga negara Indonesia yang beragama islam, sebagaimana ternyata pada Yurisprudensi Mahkamah Agung Nomor: 172K/ $\mathrm{SIP} / 1974 .^{10}$

3. Hukum waris adat, berlaku bagi golongan bumiputera yang tunduk pada hukum adat yang memiliki sifat kekeluargaan, baik itu sifat keibuan (matrilineal), sifat kebapakan (patrilineal), maupun sifat keibubapakan (bilateral atau parental). ${ }^{11}$

Ketiga sistem hukum waris ini memiliki karakteristik dan ciri khas masingmasing yang mengakibatkan terjadinya perbedaan antar yang satu dan lainnya. ${ }^{12}$ Meskipun demikian, perbedaan diantara ketiga sistem hukum waris tersebut memiliki tujuan yang sama yaitu bagaimana ahli waris mengurusi hak-hak dan kewajiban dari pewaris. Namun demikian, apabila membicarakan mengenai persoalan hukum waris, maka tidak lepas dari 3 (tiga) unsur pokok yang ada, yaitu: ${ }^{13}$

1) Pewaris (erflater)

Pewaris merupakan sebutan bagi orang yang tutup usia atau meninggal dunia dan meninggalkan harta benda kepada keturunannya atau yang mempunyai hubungan darah yang disebut juga sebagai ahli waris.

2) Waris Atau Ahli Waris (erfgenaam)

Waris atau ahli waris merupakan sebutan bagi orang yang berhak mendapatkan

\footnotetext{
${ }_{9}^{9}$ Oemar Moechthar, Op.Cit.[14]

10 ibid.

${ }^{11}$ ibid.

12 ibid. [15].

13 ibid.
} 
bagian (seluruhnya atau sebagian tertentu) dari harta benda milik pewaris.

3) Harta Warisan (nalaten schap)

Harta warisan atau disingkat warisan adalah segala harta kekayaan dan hakhak lainnya yang ditinggalkan oleh orang yang meninggal dunia atau tutup usia (pewaris), yang tentunya setelah dikurangi dengan semua utang-utang si pewaris.

Peralihan hak atas tanah atau Hak Milik Atas Satuan Rumah Susun dibagi menjadi dua bentuk: ${ }^{14}$

1. Beralih.

Berpindahnya hak atas tanah atau Hak Milik Atas Satuan Rumah Susun dari pemegang haknya kepada pihak lain karena peristiwa hukum, yaitu kematian seseorang. Peralihan hak atas tanah atau Hak Milik Atas Satuan Rumah Susun ini terjadi karena hukum, artinya dengan meninggalnya pemegang hak (subjek hukum), maka ahli warisnya memperoleh hak atas tanah atau Hak Milik Atas Satuan Rumah Susun. Dalam beralih ini, pihak yang memperoleh hak harus memenuhi syarat sebagai pemegang (subjek) hak atas tanah atau Hak Milik Atas Satuan Rumah Susun.

2. Dialihkan/Pemindahan Hak.

Pemindahan karena perbuatan hukum yang sengaja dilakukan dengan tujuan agar pihak lain tersebut memperoleh haknya sesuai dengan bagiannya.

Perbuatan hukum tersebut dapat berupa jual beli, tukar-menukar, hibah, pemasukan dalam modal perusahaan, pemberian dengan wasiat, lelang. ${ }^{15}$ Dalam dialihkan/pemindahan hak di sini, pihak yang mengalihkan/memindahkan hak harus berhak dan berwenang memindahkan hak, sedangkan bagi pihak yang memperoleh hak harus memenuhi syarat sebagai pemegang (subjek) hak atas tanah atau Hak Milik Atas Satuan Rumah Susun. ${ }^{16}$

Berkenaan dengan pengertian jual beli tanah, Boedi Harsono menyatakan bahwa pengertianjual beli tanah adalah perbuatan hukum yang berupa penyerahan

\footnotetext{
${ }^{14}$ Urip Santoso, Pendaftaran Dan Peralihan Hak Atas Tanah (Prenadamedia Group 2019).[363].

${ }^{15}$ Sri Winarsi et al., Seri Hukum Agraria : Prinsip Prioritas Dalam Sistem Hukum Agraria Indonesia (Jakad Media Publishing 2021).[68-69].

${ }^{16}$ Urip Santoso, Loc.Cit.
} 
Hak Milik (penyerahan tanah untuk selama-lamanya) oleh penjual kepada pembeli, yang pada saat itu jual pembeli menyerahkan harganya kepada penjual. Jual beli yang berakibatkan beralihnya hak milik atas tanah dari penjual kepada pembeli itu termasuk dalam hukum agraria atau hukum tanah. ${ }^{17}$ Pengertian jual beli tanah menurut Boedi Harsono, ruang lingkup objeknya terbatas hanya pada hak milik atas tanah. Dalam hukum positif, hak atas tanah yang dapat menjadi objek jual beli hanya terbatas hanya pada Hak Milik, namun juga Hak Guna Usaha, Hak Guna Bangunan, Hak Pakai, maupun Hak Milik Atas Satuan Rumah Susun. ${ }^{18}$

Sifat jual beli tanah menurut Effendi Perangin, adalah: ${ }^{19}$

a. Contant atau tunai

Contant atau tunai, artinya harga tanah yang dibayar itu bisa seluruhnya, tetapi bisa juga sebagian. Tetapi biarpun dibayar sebagian, menurut hukum dianggap telah dibayar penuh. Pembayaran harga dan penyerahan haknya dilakukan pada saat yang bersamaan. Pada saat itu, jual beli menurut hukum telah selesai. Sisa harga yang belum dibayar dianggap sebagai utang pembeli kepada bekas pemilik tanah (penjual). Ini berarti, jika kemudian pembeli tidak membayar sisa harganya, maka bekas pemilik tanah tidak dapat membatalkan jual beli tanah tersebut. Penyelesaian pembayaran sisa harga tersebut dilakukan menurut hukum perjanjian utang piutang.

b. Terang

Terang, artinya jual beli tanah tersebut dilakukan di hadapan kepala desa (kepala adat) yang tidak hanya bertindak sebagai saksi tetapi juga dalam kedudukannya sebagai pihak yang menanggung bahwa jual beli tanah tersebut tidak melanggar hukum yang berlaku. Jual beli tanah yang dilakukan di hadapan kepada desa (kepala adat) ini menjadi "terang" bukan perbuatan hukum yang "gelap", artinya pembeli mendapatkan pengakuan

\footnotetext{
${ }^{17}$ Boedi Harsono, Undang-Undang Pokok Agraria Sedjarah Penjusunan, Isi, dan Pelaksanaannja (Jambatan 1971).[135].

${ }^{18}$ Urip Santoso, Op.Cit.[360].

${ }^{19}$ Effendi Perangin, Hukum Agraria Indonesia Suatu Telaah Dari Sudut Pandangan Praktisi Hukum (Rajawali 1989).[16].
} 
dari masyarakat yang bersangkutan sebagai pemilik tanah yang baru dan mendapatkan perlindungan hukum jika dikemudian hari ada gugatan terhadapnya dari pihak yang menganggap jual beli tanah tersebut tidak sah.

Sedangkan, pewarisan yang dimaksud di sini adalah pewarisan hak atas tanah. Dalam praktik disebut pewarisan tanah. Secara yuridis, yang diwariskan adalah hak atas tanah bukan tanahnya. ${ }^{20}$ Memang benar bahwa tujuan pewarisan hak atas tanah adalah supaya ahli warisnya dapat secara sah menguasai dan menggunakan tanah atau satuan rumah susun yang bersangkutan. Dalam perkembangannya, yang diwariskan tidak hanya berupa hak atas tanah, tetapi juga Hak Milik Atas Satuan Rumah Susun. ${ }^{21}$

Jika dihubungkan dengan permasalahan dalam penelitian ini, maka sudah pasti adanya perpindahan harta kekayaan yang salah satunya berupa hak milik atas tanah dari seseorang yang meninggal dunia yaitu si pewaris kepada keturunannya atau seseorang yang memiliki hubungan darah dengan si pewaris yaitu biasa disebut ahli waris. Perpindahan harta kekayaan yang salah satunya berupa hak milik atas tanah ini berpindah dikarenakan adanya kematian atau meninggal dunia sehingga terjadilah peristiwa hukum atau beralih secara hukum (demi hukum).

Pengertian warga negara menurut Pasal 26 ayat (1) UUD NRI 1945 dinyatakan bahwa "Yang menjadi warga negara ialah orang-orang bangsa Indonesia dan orang-orang bangsa lain yang disahkan dengan undang-undang sebagai warga negara". Sedangkan menurut Pasal 2 Undang-Undang Nomor 12 Tahun 2006 Tentang Kewarganegaraan Republik Indonesia, pengertian warga negara Indonesia adalah orang-orang bangsa Indonesia asli dan orang-orang bangsa lain yang disahkan dengan Undang-Undang sebagai warga negara. Pengertian Warga Negara Asing menurut Pasal 7 Undang-Undang Nomor 12 Tahun 2006 Tentang Kewarganegaraan Republik Indonesia, yaitu warga negara asing adalah setiap orang yang bukan warga negara Indonesia diperlakukan sebagai orang

\footnotetext{
${ }^{20}$ ibid.[397].
}

${ }^{21}$ ibid. 
asing. Pengertian warga negara asing yaitu seseorang yang tinggal dan menetap di sebuah negara tertentu namun bukan berasal dari negara tersebut juga tidak secara resmi terdaftar sebagai warga negara, yang memiliki tujuan beragam, misalnya dalam rangka menempuh pendidikan, bisnis maupun hal lainnya. Meskipun status seseorang tersebut adalah warga negara asing di Indonesia, seseorang tersebut tetap memiliki hak dan juga kewajiban terhadap negara yang di tinggalinya. Sedangkan pada Pasal 1 ayat (9) Undang-Undang Nomor 6 Tahun 2011 Tentang Keimigrasian disebutkan bahwa orang asing adalah orang yang bukan warga negara Indonesia.

Seseorang atau warga negara asing atau yang biasanya disingkat sebagai WNA, Selanjutnya disebut sebagai WNA tersebut yang tinggal di Indonesia memiliki hak dan kewajiban yang harus dijalankan, berikut hak dan kewajiban yang dimiliki WNA selama tinggal di Indonesia: ${ }^{22}$

1. Berhak atas perlindungan terhadap hak-hak asasinya termasuk hak perlindungan atas diri maupun harta benda yang dimiliki WNA tersebut, selama dalam proses yang resmi;

2. Berkewajiban untuk tunduk serta mematuhi segala ketentuan perundangan yang berlaku di negara Indonesia;

3. Tidak berhak untuk ikut serta dalam sebuah organisasi politik maupun instansi pemerintah;

4. Tidak berhak untuk ikut serta dalam sistem pemilu di Indonesia, baik untuk memilih ataupun dipilih;

5. Tidak berkewajiban untuk ikut serta dalam program bela negara.

Sehubungan dengan kepemilikan hak atas tanah warga negara asing diatur pada Pasal 21 ayat (3) UUPA yang berbunyi yaitu:

“Orang asing yang sesudah berlakunya Undang-undang ini memperoleh hak milik karena pewarisan tanpa wasiat atau percampuran harta karena perkawinan, demikian pula warga negara Indonesia yang mempunyai hak milik dan setelah berlakunya undang-undang ini kehilangan kewarganegaraannya wajib melepaskan hak itu di dalam jangka waktu satu tahun sejak diperolehnya hak tersebut atau hilangnya kewarganegaraan itu. Jika sesudah jangka waktu tersebut lampau hak milik itu tidak dilepaskan,

${ }^{22}$ Afndolah Novianta Tarigan, PenyidikanTerhadapWarga Negara Asing Yang Melakukan Penyalahgunaan Visa Kunjungan (Studi Di Kantor Imigrasi Kelas I Khusus Kota Medan (Universitas Muhammadiyah Sumatera Utara 2019).[21]. 
maka hak tersebut hapus karena hukum dan tanahnya jatuh pada Negara, dengan ketentuan bahwa hak-hak pihak lain yang membebaninya tetap berlangsung".

Pada pasal tersebut sangatjelas disebutkan bahwa "warga negara asing yang memperoleh hak milik karena pewarisan" dan "warga negara Indonesia yang mempunyai hak milik dan setelah berlakunya undang-undang ini kehilangan kewarganegaraannya" diwajibkan untuk melepaskan haknya dengan batas waktu maksimal sejak memperoleh hak atau sejak tidak lagi menjadi warga negara Indonesia.

Jika melihat Pasal 144 Undang-Undang Nomor 11 Tahun 2020 tentang Cipta Kerja (UU Cipta Kerja) dijelaskan bahwa Hak Milik atas satuan rumah susun dapat diberikan kepada subjek hukum yang salah satunya yaitu warga negara asing yang mempunyai izin sesuai dengan ketentuan peraturan perundangundangan, kemudian dalam Pasal 5 dijelaskan pula bahwa orang asing diberikan Hak Pakai untuk rumah tunggal pembelian baru dah Hak Milik atas satuan rumah susundi atas Hak Pakai untuk Sarusun pembelian unit baru, artinya bahwa warga negara asing saat ini diperbolehkan memiliki hunian rumah susun atau apartemen dengan status Hak Milik secara penuh sedangkan sebelumnya hanya diperbolehkan hanya memiliki Hak Milik atas Sarusun di atas Hak Pakai untuk Sarusun pembelian unit baru.

Pembagian hak atas tanah waris warga negara Indonesia yang ditinggalkan oleh pewaris untuk ahli waris berupa tanah namun setelahnya mengubah kewarganegaraan, maka terdapat beberapa ketentuan yang harus dijalani berkaitan dengan UUPA. Dengan berpindahnya kewarganegaraan akan berdampak pada hilangnya hak milik atas tanah namun dalam hal waris sedikit berbeda. Larangan kepemilikan tanah oleh Warga Negara Indonesia (selanjutnya disebut sebagai WNI) yang berpindah kewarganegaraan bukan menyebabkan hak warisnya tersebut gugur, solusinya ahli waris dapat memperoleh ganti dalam bentuk uang tunai atau hasil penjualan atas tanah waris, hal ini berdasarkan ketentuan Pasal 1 ayat (3) UUPA. Dalam jangka waktu 1 (satu) tahun orang yang telah mengubah kewarganegaraannya sudah harus melakukan pengalihan atas tanah 
yang diwarisi, jika tidak, tanah tersebut akan jatuh kepada negara. Pengalihan hak milik tanah yang diwarisi dapat dilakukan dengan meminta kepada Badan Pertanahan Nasional agar tanah tersebut statusnya diturunkan menjadi hak pakai, menghibahkan kepada subjek hak milik lain, atau dengan menjual tanah tersebut. Status hak atas tanah waris bagi warga negara Indonesia yang beralih kewarganegaraan tersebut ialah berstatus hak pakai, bilamana ia mengalihkan hak milik atas tanahnya menjadi hak pakai agar ia tetap dapat menggunakan tanahnya dengan status hak pakai atas tanah.

Sehubungan dengan permasalahan penelitian ini, maka pada dasarnya warga negara asing tidak dapat menguasai hunian apapun yang berstatus Hak Milik hanya saja setelah ditetapkannya UU Cipta Kerja yang menyebutkan bahwa warga negara asing hanya dapat menguasai hunian yang berstatus Hak Milik Atas Satuan Rumah Susun.

Obyek harta waris yang difokuskan pada penelitian ini yaitu berupa Hak Milik Atas Tanah. Pada UU Cipta Kerja tidak disebutkan mengenai penguasaan tanah warga negara asing yang berstatus Hak Milik sehingga penguasaan tanah warga negara asing yang berstatus Hak Milik masih mengacu pada UUPA dan perundang-undangan yang berlaku. Mengenai peraturan-peraturan tentang pertanahan yang telah ada pada kenyataannya masih in-line dan berpedoman pada pasal 33 ayat (3) UUD 1945 dimana bumi dan air dan kekayaam alam yang terkandung di dalamnya dikuasai oleh negara dan dipergunakan untuk kemakmuran rakyat Indonesia sehingga akan sangat menyimpang jika Hak Milik Atas Tanah dapat dikuasai oleh warga negara asing untuk tujuan apapun.

Adapun permasalahan pada penelitian ini bermula saat terjadinya kecelakaan kendaraan yang mengakibatkan 2 (dua) orang berketurunan bumi putera meninggal dunia di Desa Sidomukti, Kecamatan Jatirogo, Kabupaten Tuban, Provinsi Jawa Timur pada tahun 2013. Kedua orang tersebut adalah sepasang suami istri beragama islam dan keturunan bumi putera meninggal dunia yang memiliki 4 (empat) orang anak. Sepasang suami istri tersebut selain memiliki 4 (empat) orang anak juga memiliki 4 (empat) bidang tanah. Dikarenakan suami 
istri tersebut meninggal dunia maka timbulah pewarisan dimana sepasang suami istri yang meninggal dunia disebut sebagai pewaris, 4 (empat) orang anak yang ditinggalkan disebut sebagai ahli waris, dan harta benda berupa beberapa bidang tanah disebut sebagai harta waris. Dengan adanya kematian maka timbulah waris sehingga harta benda pewaris beralih kepada ahli waris pada tahun 2014 dan sudah dibalik nama kepada masing-masing ahli waris yang besarannya sesuai dengan porsi masing-masing. Kemudian pada bulan Desember 2020 ternyata salah satu ahli waris menikah dan mengikuti pasangannya yang bekerja di Qatar sehingga berpindah kewarganegaraan menjadi warga negara Qatar. Permasalah hukum pada kronologis ini terlihat bahwa salah satu ahli waris yang berpindah kewarganegaraan menjadi warga negara asing tersebut masih menguasai hak atas tanah yang berstatus Hak Milik sedangkan penguasaan Hak Atas Tanah yang berstatus Hak Milik yang dimiliki oleh warga negara asing wajib dilepaskan dengan jangka waktu selama 1 (satu) tahun dan apabila sudah jatuh tempo maka akan menjadi tanah negara status Hak Milik menjadi hapus. Si ahli waris yang telah berkewarganegraan asing tersebut rencananya akan mengalihkan aset tanah yang berasal dari pewarisan tersebut pada bulan Februari 2021.

Berdasarkan pada Pasal 23 ayat (3) UUPA maka warga negara indonesia yang telah berpindah kewarganegaraan asing atau warga negara asing yang memiliki keturunan ahli waris atau hubungan darah dari seseorang yang berwarganegara Indonesia yang meninggal dunia masih mendapatkan haknya menjadi ahli waris dan dapat memiliki hak atas tanah yang berstatus hak milik dari harta waris tersebut. Kepemilik hak atas tanah yang berstatus hak milik tersebut tentunya dibatasi jangka waktu maksimal 1 (satu) tahun sehingga dari jangka waktu tersebut maka pemilik yang telah berstatus warga negara asing wajib mengalihkan haknya kepada orang lain yang berkewarganegara Indonesia. Adapun pengalihan tersebut sesuai pada Pasal 37 ayat (1) Peraturan Pemerintah Nomor 24 Tahun 1997 yaitu dapat melalui jual beli, tukar menukar yang obyeknya bukan kepemilikan hak atas tanah misalnya hak milik tanah warga negara asing ditukar dengan apartemen/rumah susun yang berstattus hak milik, hibah, dan lelang. 
Adapun setelah jangka waktu maksimal 1 (satu) tahun ternyata warga negara asing yang menguasai tanah yang berstatus hak milik tidak mengalihkan haknya maka tanah tersebut akan beralih dengan sendirinya menjadi tanah negara sehingga warga negara asing yang menguasai tanah tersebut seolah-olah melepaskan haknya atau kehilangan haknya. Jika ternyata tanah tersebut beralih menjadi tanah negara maka warga negara asing tersebut masih diberikan hak oleh negara untuk mengajukan permohonan kepada negara untuk mendapatkan tanah tersebut dengan status hak pakai, hal ini telah diatur dalam Pasal 49 Peraturan Pemerintah Nomor 18 Tahun 2021 tentang Hak Pengelolaan, Hak Atas Tanah, Satuan Rumah Susun, Dan Pendaftaran Tanah. Penguasaan warga negara asing atas tanah yang berstatus Hak Pakai juga memiliki jangka waktu yang telah diatur dalam Pasal 52 ayat (1) Peraturan Pemerintah Nomor 18 Tahun 2021 yaitu jangka waktu paling lama 30 (tiga puluh) tahun diperpanjang untuk jangka waktu paling lama 20 (dua puluh) tahun, dan diperbarui untuk jangka waktu paling lama 30 (tiga puluh) tahun.

\section{Keabsahan Penguasaan Hak Atas Tanah Yang Dilakukan Oleh Warga Negara} Asing Atas Obyek Yang Berasal Dari Pewarisan Berkewarganegaraan Indonesia

Masalah pertanahan merupakan suatu masalah yang tidak terlepaskan dari perkembangan pembangunan suatu kota sehingga pemerintah berupaya untuk menangani permasalahan ini dengan hati-hati. Berbagai permasalahan pertanahan yang timbul mengindikasikan bahwa masalah pertanahan yang timbul dapat menjadi prioritas. Adapun penyebab terjadinya permasalahan di bidang pertanahan ini akibat dari terbatasnya ketersediaan tanah yang ada, adanya peralihan hak atas tanah yang timbul karena pewarisan, pemilik hak atas tanah yang beralih menjadi warga negara asing, tumpang tindih peraturan mengenai penguasaan tanah, klaim antar pemegang hak atas tanah yang sama yang disebabkan karena praktek manipulasi perolehan hak atas tanah pada masa lalu sehingga menimbulkan gugatan, dan lain sebagainya. 
Konsep hak-hak atas tanah yang terdapat dalam hukum agraria nasional membagi hak-hak atas tanah dalam dua bentuk: ${ }^{23}$

1. hak-hak atas tanah yang bersifat primer yaitu hak-hak atas tanah yang dapat dimiliki atau dikuasai secara langsung oleh seorang atau badan hukum yang mempunyai waktu lama dan dapat dipindahtangankan kepada orang lain atau ahli warisnya seperti Hak Milik (HM), Hak Guna Usaha (HGU), Hak Guna Bangunan (HGB), Hak Pakai (HP).

2. hak-hak atas tanah yang bersifat sekunder yaitu hak-hak atas tanah yang bersifat sementara seperti hak gadai, hak usaha bagi hasil, hak menumpang, dan hak menyewa atas tanah pertanian.

Dari beberapa macam kepemilikan hak atas tanah tersebut di atas, hak milik merupakan satu-satunya hak yang terkuat dan terpenuh yang dapat dipunyai orang atas tanah dan hak yang mempunyai kedudukan paling tinggi jika dibandingkan dengan hak-hak lainnya, sesuai dengan ketentuan pada Pasal 20 ayat (1) UUPA yang disebutkan bahwa Hak milik adalah hak turun temurun, terkuat, terpenuh, yang dapat dipunyai orang atas tanah. Turun temurun artinya hak milik atas tanah dapat berlangsung terus selama pemiliknya masih hidup dan bila pemiliknya meninggal dunia, maka hak miliknya dapat dilanjutkan oleh ahli warisnya sepanjang memenuhi syarat sebagai subjek hak milik. Terkuat artinya hak milik atas tanah lebih kuat dibandingkan dengan hak atas tanah yang lain, tidak mempunyai batas waktu tertentu, mudah dipertahankan dari gangguan pihak lain, dan tidak mudah hapus. Terpenuh artinya hak milik atas tanah memberi wewenang kepada pemiliknya lebih luas bila dibandingkan dengan hak atas tanah yang lain, dapat menjadi induk bagi hak atas tanah yang lain, dan penggunaan tanahnya lebih luas bila dibandingkan dengan hak atas tanah yang lain. ${ }^{24}$

Dengan adanya seseorang yang meninggal dunia atau kematian maka kepemilikan seseorang atas tanah tersebut berakhir karena dengan adanya

\footnotetext{
${ }^{23}$ Supriadi, Hukum Agraria (Sinar Grafika 2007).[64].

${ }^{24}$ Urip Santoso, Hukum Agraria \& Hak-Hak Atas Tanah (Kencana Prenada Media Group 2007).
} [90-91]. 
peristiwa hukum ini mengakibatkan adanya peralihan harta benda kekayaan dari seseorang yang meninggal dunia kepada ahli waris orang yang meninggal dunia tersebut. Dengan peristiwa kematian atau meninggal dunia ini maka akan ada pewaris, ahli waris, dan harta waris.

Dari ketentuan tersebut di atas, dapat disimpulkan bahwa mewaris adalah menggantikan hak dan kewajiban seseorang yang meninggal. Pada umumnya yang digantikan hanya hak dan kewajiban di bidang hukum kekayaan saja. Hukum waris itu sendiri merupakan hukum yang mengatur mengenai apa yang harus terjadi dengan harta kekayaan seseorang yang meninggal dunia, mengatur peralihan harta kekayaan yang ditinggalkan oleh seseorang yang meninggal, serta akibat-akibatnya bagi para ahli waris. ${ }^{25}$

Subjek dari Hak Milik Atas Tanah adalah warga negara Indonesia dan badan-badan hukum yang tetapkan oleh pemerintah berdasarkan syarat-syarat dari ketentuan yang berlaku. Hal ini sesuai dengan ketentuan Pasal 21 ayat (1) UUPA yaitu: "Hanya warga negara Indonesia dapat mempunyai Hak Milik” dan pada ayat (2) yaitu: “Oleh Pemerintah ditetapkan badan-badan hukum yang dapat mempunyai hak milik dan syarat-syaratnya".

Hak Milik atas tanah dapat terjadi melalui dua cara, hal ini sesuai dengan ketentuan Pasal 22 UUPA yaitu: Hak Milik atas tanah yang terjadi menurut Hukum Adat, Hak Milik atas tanah yang terjadi karena penetapan oleh pemerintah, Hak Milik atas tanah terjadi karena ketentuan undang-undang. Hak Milik atas tanah juga dapat terjadi melalui 2 (dua) cara yaitu: ${ }^{26}$

1. Secara originair merupakan terjadinya Hak Milik atas tanah untuk pertama kalinya menurut hukum adat, penetapan pemerintah dan karena undangundang;

2. Secara derivatif merupakan terjadinya Hak Milik atas tanah dimana suatu subjek hukum memperoleh tanah dari subjek hukum lain yang semula sudah berstatus tanah Hak Milik, misalnya jual beli, tukarmenukar, hibah, pewarisan.

\footnotetext{
${ }^{25}$ ibid.[11].

${ }^{26}$ Urip Santoso, Hukum Agraria Kajian Komprehensif (Kencana Prenadamedia Group 2014).[98].
} 
Akibat dari terjadinya perbuatan hukum atau peristiwa hukum tersebut, maka Hak Milik atas tanah yang sudah ada beralih atau berpindah dari subjek hukum yang satu kepada subjek hukum yang lainnya.

Adapun mekanisme mengenai peralihan hak karena pewarisan telah diatur pada Pasal 42 PP 24/1997 yaitu:

a. untuk pendaftaran peralihan hak karena pewarisan mengenai bidang tanah hak yang sudah didaftar dan hak milik atas satuan rumah susun, maka wajib diserahkan oleh yang menerima hak atas tanah atau hak milik atas satuan rumah susun yang bersangkutan sebagai warisan kepada orang yang namanya dicatat sebagai pemegang haknya dan surat tanda bukti sebagai ahli waris.

b. Jika penerima warisan terdiri dari satu orang, pendaftaran peralihan hak tersebut dilakukan kepada orang tersebut berdasarkan surat tanda bukti sebagai ahli waris.

c. Jika penerima warisan lebih dari satu orang dan waktu peralihan hak tersebut didaftarkan disertakan dengan akta pembagian waris yang memuat keterangan bahwa hak atas tanah atau hak milik atas satuan rumah susun tertentu jatuh kepada seorang penerima warisan tertentu, pendaftaran peralihan hak atas tanah atau hak milik atas satuan rumah susun itu dilakukan kepada penerima warisan yang bersangkutan berdasarkan surat tanda bukti sebagai ahli waris dan akta pembagian waris tersebut.

d. Warisan berupa hak atas tanah atau hak milik atas satuan rumah susun yang menurut akta pembagian waris harus dibagi bersama antara beberapa penerima warisan atau waktu didaftaran belum ada akta pembagian warisnya, didaftar peralihan haknya kepada para penerima waris yang berhak sebagai hak bersama mereka berdasarkan surat tanda bukti sebagai ahli waris dan/ atau akta pembagian waris tersebut.

Pada dasarnya pemberian hak atas tanah Negara adalah pemberian hak atas tanah yang dikuasai langsung oleh negara kepada seseorang ataupun beberapa orang bersama-sama atau suatu badan hukum. Adapun mengenai pihak-pihak yang dapat menguasai hak atas tanah telah diatur dalam Pasal 9 ayat (2) UUPA yang menyatakan bahwa tiap-tiap warga negara Indonesia, baik Laki-laki maupun perempuan mempunyai kesempatan yang sama untuk memperoleh sesuatu hak atas tanah untuk mendapat manfaat dan hasilnya, baik bagi diri sendiri maupun keluarganya. Sedangkan yang bukan merupakan warga negara Indonesia atau badan hukum asing yang mempunyai perwakilan di Indonesia sangat dibatasi, hanya hak pakai dan hak sewa saja yang sebagaimana telah diatur dalam Pasal 42 dan Pasal 45 UUPA. 
Hak Milik atas tanah dan bangunan merupakan hak yang hanya berlaku bagi warga negara Indonesia sedangkan warga negara asing hanya memiliki hak atas tanah berupa hak pakai dan hak sewa untuk bangunan, dimana kedua hak ini juga berlaku bagi warga negara Indonesia. Jika dilihat dari subyek hak sebagaimana yang diatur dalam Pasal 16 UUPA, ternyata hak terkuat adalah hak milik sedangkan hak ini hanya dapat dimiliki oleh warga negara Indonesia. Hak milik itu mempunyai ciri-ciri sebagai berikut: ${ }^{27}$

a. Hak milik adalah hak yang terkuat dan terpenuh, artinya hak milik adalah yang paling kuat jika dibandingkan dengan hak-hak lainnya dan dapat dipertahankan oleh pemegang haknya dari gangguan pihak lain;

b. Hak milik dapat dibebani dengan hak-hak lainnya, seperti hak guna usaha, hak pakai, hak sewa, hak tanggungan, dan hak-hak lainnya;

c. Hak milik tidak mempunyai jangka waktu berlakunya, sampai kapanpun dan dapat diwariskan kepada ahli warisnya;

d. Hanya hak milik yang dapat diwakafkan, hak-hak lain tidak dapat diwakafkan.

e. Hak milik hanya dapat dimiliki oleh warga negara Indonesia dan badan hukum Indonesia.

Hapusnya hak milik terjadi karena tanahnya jatuh kepada negara dan tanahnya musnah. Mengenai jatuhnya tanah kepada negara dapat disebabkan karena pencabutan hak berdasarkan Pasal 18 UUPA. Penyerahan secara sukarela oleh pemiliknya, karena ditelantarkan, dan karena ketentuan Pasal 21 ayat (3) dan Pasal 26 ayat (2) UUPA. Mengenai kriteria tanah terlantar telah diatur dalam Peraturan Pemerintah Nomor 11 Tahun 2010. ${ }^{28}$ Sedangkan kepemilikan warga negara asing di Indonesia, sebagaimana yang tercantum dalam Pasal 42 UUPA bahwa Subjek Hak Pakai diatur dalam Pasal 42 UUPA, yaitu:

a. Warga negara Indonesia;

b. Orang asing yang berkedudukan di Indonesia;

c. Badan hukum yang didirikan menurut hukum Indonesia dan berkedudukan di Indonesia (badan hukum Indonesia);

d. Badan hukum asing yang mempunyai perwakilan di Indonesia.

Kemudian, hal tersebut diatur pula pada Pasal 49 ayat (2) Peraturan Pemerintah Nomor 18 Tahun 2021 tentang Hak Pengelolaan, Hak Atas Tanah,

\footnotetext{
${ }^{27}$ Arba, Hukum Agraria Indonesia (Sinar Grafika 2016).[98].

${ }^{28}$ Sri Hajati, et.al.,Op.Cit.[76].
} 
Satuan Rumah Susun, Dan Pendaftaran Tanah disebutkan bahwa subjek hak pakai yaitu:

a. Warga Negara Indonesia;

b. badan hukum yang didirikan menurut hukum Indonesia dan berkedudukan di Indonesia;

c. badan hukum asing yang mempunyai perwakilan di Indonesia;

d. badan keagamaan dan sosial; dan

e. orang asing.

Jadi pada dasarnya warga negara asing yang tinggal di Indonesia hanya bisa memiliki tanah dan bangunan sebatas hak pakai dan hak sewa. Hal ini diatur lebih rinci lagi dalam Pasal 3 Permen Agraria 29/2016:

1. Orang Asing pemegang izin tinggal di Indonesia sesuai dengan ketentuan peraturan perundangundangan, dapat memiliki rumah untuk tempat tinggal atau hunian dengan Hak Pakai.

2. Dalam hal Orang Asing meninggal dunia, maka rumah tempat tinggal atau hunian sebagaimana dimaksud pada ayat (1) dapat diwariskan.

3. Dalam hal ahli waris sebagaimana dimaksud pada ayat (2) merupakan Orang Asing, maka ahli waris harus mempunyai izin tinggal di Indonesia sesuai ketentuan peraturan perundang-undangan.

Pengertian Hak Pakai disebutkan dalam Pasal 41 ayat (1) UUPA yaitu hak pakai adalah hak untuk menggunakan dan atau memungut hasil tanah yang dikuasai langsung oleh negara atau tanah milik orang lain yang memberikan wewenangan dan kewajiban yang ditentukan dalam keputusan pemberiannya oleh pejabat yang berwenang memberikannya atau dalam perjanjian dengan pemilik tanahnya, yang bukan perjanjian sewa menyewa tanah, atau perjanjian pengolahan tanah, segala sesuatu asal tidak bertentangan dengan jiwa dan ketentuan UUPA. Dalam pengertian Hak Pakai terkandung bahwa:

a. Hak Pakai adalah hak untuk menggunakan tanah dan/atau memungut hasil dari tanah;

b. Tanah Hak Pakai bisa untuk keperluan mendirikan bangunan dan atau pertanian, perikanan, peternakan, atau perkebunan;

c. Tanah Hak Pakai berasal dari tanah yang dikuasai langsung oleh negara atau tanah milik orang lain;

d. Hak Pakai terjadi dengan keputusan pemberian hak atau dengan perjanjian 
pemberian hak dengan pemilik tanah;

e. Perjanjian pemberian hak antara pemegang Hak Pakai dan pemilik tanah bukan perjanjian sewa menyewa tanah, atau perjanjian pengolahan tanah.

Mengenai rumah tempat tinggal atau hunian yang dapat dimiliki oleh warga negara asing pada tersebut diatas yaitu merupakan rumah tinggal di atas tanah hak pakai atau hak pakai di atas Hak Milik yang dikuasai berdasarkan perjanjian pemberian Hak Pakai di atas Hak Milik dengan akta Pejabat Pembuat Akta Tanah. Mengenai jangka waktu pemberian hak pakai tersebut diberikan untuk jangka waktu 30 (tiga puluh) tahun, dapat diperpanjang untuk jangka waktu 20 (dua puluh) tahun, dan dapat diperpanjang kembali untuk jangka waktu 30 (tiga puluh) tahun), hal ini sesuai dengan Pasal 52 Peraturan Pemerintah Nomor 18 Tahun 2021 tentang Hak Pengelolaan, Hak Atas Tanah, Satuan Rumah Susun, Dan Pendaftaran Tanah.

Adapun subyek pemegang hak pakai yaitu warga negara asing atau ahli waris yang berpindah kewarganegaraan menjadi warga negara asing yang memiliki rumah yang dibangun di atas tanah Hak Pakai atau berdasarkan perjanjian dengan pemegang hak atas tanah tidak lagi berkedudukan di Indonesia, dalam jangka waktu 1 (satu) tahun wajib melepaskan atau mengalihkan hak atas rumah dan tanahnya kepada pihak lain yang memenuhi syarat.

Pada dasarnya warga negara asing tidak dapat menguasai hak atas tanah dengan status hak milik tetapi masih dimungkinkan bagi warga negara asing untuk menguasai hak atas tanah dengan status hak milik sebagaimana yang diatur dalam Pasal 21 UUPA, yaitu warga negara asing yang menguasai hak atas tanah dengan status hak milik karena sebagai berikut:

1. Pewarisan secara ab-intestato (menurut undang-undang), artinya yang merupakan faktor penentu dalam hubungan pewarisan yaitu adanya hubungan darah antara pewaris dan ahli waris;

2. Perkawinan campur dengan persekutuan harta, artinya seseorang yang berwarganegaraan indonesia menikah dengan seseorang yang berwarganegaraan asing kemudian membeli tanah yang berstatus hak milik yang diatasnamakan seseorang yang berwarganegaraan indonesia; 
3. Peralihan kewarganegaraan dari warga negara Indonesia menjadi warga negara asing, artinya seseorang yang berpindah kewarganegaraan tersebut masih menguasai hak atas tanah berstatus hak milik.

Salah satu tujuan dari hukum waris yaitu mengontrol mengenai beralihnya harta kekayaan yang ditinggalkan oleh seorang yang meninggal dunia juga dampakya kepada ahli waris. Terkait pemindahan hak atas tanah dari pewaris ke ahli warisnya yang mempunyai kewarganegaraan berbeda, terdapat adanya pembatasan-pembatasan terkait pemindahan hak atas tanah tersebut yaitu membatasi terkait kecakapan berhak dalam hal ini yaitu kewarganegaraan, menurut UUPA disebutkan sejatinya hanya Warga Negara Indonesia yang bisa memiliki keterkaitan sepenuhnya terhadap air, bumi, dan ruang angkasa. Pernyataan tersebut kemudian diperjelas kembali dalam UUPA hanya warga negara Indonesia yang dapat mempunyai hak milik. Hal ini menunjukkan bahwa bagi WNA yang berkedudukan di Indonesia dapat diberikan hak pakai sebagaimana tercantum dalam Pasal 42 UUPA. Upaya hukum yang dilakukan oleh ahli waris yang menjadi Warga Negara Asing terkait hak milik atas tanah kepunyaanya oleh karena warisan ada beberapa cara, yaitu:

1. Ahli waris yang telah pindah kewarganegaraan dan berhak menerima warisan dari pewaris yang merupakan warga negara Indonesia bisa meminta permohonan kembali tentang keinginannya untuk tetap menjadi warga negara Indonesia sesuai ketentuan UU Kewarganegaraan Indonesia dan PP tentang Tata Cara Memperoleh, Kehilangan, Pembatalan, dan Memperoleh Kembali Kewarganegaraan Republik Indonesia sehingga ahli waris yang telah menjadi warga negara asing tersebut berhak memperoleh kembali hak-hak sebagaimana warga negara Indonesia.

2. Ahli waris yang tetap tercatat sebagai warga negara asing namun bertempat tinggal di Indonesia dan tidak mengurus atau menjual sehingga sudah melewati limit waktu 1 tahun dari ketentuan UUPA, maka tanah tersebut jatuh pada negara tetapi orang asing itu dapat memakai hak pakai demi membangun bangunan sesuai perumusan dalam UUPA. 
3. Peralihan hak milik karena warisan oleh ahli waris yang menjadi warga negara asing bisa dilakukan melalui proses jual beli atau hibah pada warga negara Indonesia dalam waktu 1 tahun, sehingga ahli waris yang pindah kewarganegaraan tersebut tidak lagi memiliki properti di Indonesia dan hanya memperoleh uang dari hasil menjual tersebut.

Jika dikaitan dengan permasalahan dalam penelitian ini yaitu dimana salah satu ahli waris pada bulan Desember tahun 2020 resmi berpindah kewarganegaraan menjadi warga negara Qatar sedangkan ahli waris tersebut masih memiliki hak milik atas tanah yang berasal dari pewarisan, lalu dihubungkan dengan adanya aturan mengenai kepemilikan hak milik atas tanah dalam Pasal 21 ayat (1) UUPA maka sudah sangat jelas bahwa hanya warga negara Indonesia yang dapat memiliki hak milik atas tanah sehingga apabila ada warga negara asing yang masih memiliki hak milik atas tanah maka warga negara asing tersebut dapat melakukan upaya hukum sebagai berikut:

1. Melakukan pengalihan atas tanah dan atau bangunan dengan cara menjual, tukar-menukar, hibah, atau lelang dengan jangka waktu maksimal 1 (satu) tahun, sesuai dengan ketentuan Pasal 21 ayat (3) UUPA.

2. Apabila lebih dari jangka waktu 1 (satu) tahun tetap juga ahli waris tidak melakukan perbuatan hukum maka tanah tersebut menjadi tanah negara dan ahli waris berhak untuk mengajukan permohonan kepada Badan Pertanahan Nasional setempat supaya tanah tersebut statusnya diturunkan menjadi hak pakai sesuai ketentuan Pasal 49 PP 18/2021.

Sehubungan dengan proses waris bahwa dengan adanya kematian maka demi hukum seketika telah terjadi peralihan hak atas harta benda pewaris kepada ahli waris hanya saja perlu dilakukan pemeliharaan dokumen tanah sebagai asas publisitas pada hukum pertanahan. Adapun mengenai peralihan hak karena kematian, perlu adanya surat tanda bukti sebagai ahli waris. Mengenai tata cara surat tanda bukti sebagai ahli waris telah diatur pada Pasal 111 ayat 1 huruf c Peraturan Menteri Agraria/Kepala Badan Pertanahan Nasional Nomor 3 Tahun 1997 Tentang Ketentuan Pelaksanaan Peraturan Pemerintah Nomor 24 Tahun 
1997 Tentang Pendaftaran Tanah, surat tanda bukti sebagai ahli waris yang dapat berupa:

1) wasiat dari pewaris, atau

2) putusan Pengadilan, atau

3) penetapan hakim/Ketua Pengadilan, atau

4) surat tanda bukti sebagai ahli waris dapat dibuat:

a. bagi warganegara Indonesia penduduk asli: surat keterangan ahli waris yang dibuat oleh para ahli waris dengan disaksikan oleh 2 (dua) orang saksi dan dikuatkan oleh Kepala Desa/Kelurahan dan Camat tempat tinggal pewaris pada waktu meninggal dunia;

b. bagi warganegara Indonesia keturunan Tionghoa: akta keterangan hak mewaris dari Notaris,

c. bagi warganegara Indonesia keturunan Timur Asing lainnya: surat keterangan waris dari Balai Harta Peninggalan.

Mengenai Dwi Kewarganegaraan dapat dlihat pada Undang-Undang

Nomor 12 Tahun 2006 Tentang Kewarganegaraan Republik Indonesia (UU Kewarganegaraan) yang menyebutkan bahwa untuk memenuhi tuntutan masyarakat dan melaksanakan amanat Undang-Undang Dasar, undang-undang ini memperhatikan asas-asas kewarganegaraan umum atau universal, yaitu asas isu sanguinis, ius soli, dan campuran. Adapun asas-asas yang dianut dalam UU Kewarganegaraan adalah sebagai berikut: ${ }^{29}$

a. Asas Ius Sanguinis (law of the blood) adalah asas yang menentukan kewarganegaraan seseorang berdasarkan keturunan, bukan berdasarkan negara tempat kelahiran;

b. Asas Ius Soli (law of the soli) adalah asas yang menentukan kewarganegaraan seseorang berdasarkan negara tempat kelahiran, yang diberlakukan terbatas bagi anak-anak sesuai dengan ketentuan yang diatur dalam undang-undang ini;

c. Asas Kewarganegaraan Tunggal adalah asas yang menentukan satu kewarganegaraan bagi setiap orang;

d. Asas Kewarganegaraan Ganda Terbatas adalah asas yang menentukan kewarganegaraan ganda bagi anak-anak sesuai dengan ketentuan yang diatur dalam undang-undang ini.

Dalam penjelasan UU Kewarganegaraan dikatakan bahwa pada dasarnya UU Kewarganegaraan tidak mengenal kewarganegaraan ganda (bipatride) ataupun

${ }^{29}$ Tri Jata Ayu Premaesti, 'Bolehkan Warga Negara Indonesia Berkewarganegaraan Ganda?'<https://www.hukumonline.com/klinik/detail/ulasan/cl822/bolehkah-wniberkewarganegaraan-ganda> accessed 26 April 2021. 
tanpa kewarganegaraan (apatride). Kewarganegaraan ganda yang diberikan kepada anak-anak dalam UU Kewarganegaraan merupakan suatu pengecualian. Jadi memang dalam hukum di Indonesia tidak memperbolehkan warga negaranya berkewarganegaraan ganda.

\section{Kesimpulan}

1. Waris timbul dengan adanya kematian dan berdasarkan prinsip pewarisan di Indonesia mengenai hubungan darah sehingga yang berhak mewaris hanyalah orang-orang yang mempunyai hubungan darah dengan pewaris atau keturunan pewaris, meskipun ahli waris tersebut yang awalnya warga negara Indonesia kemudian berganti menjadi warga negara asing atau ahli waris tersebut telah menjadi warga negara asing pada saat adanya kematian maka masih tetap memperoleh haknya sebagai ahli waris. Perpindahan kewarganegaraan ahli waris dari warga negara Indonesia menjadi warga negara asing tidak serta merta menghapuskan haknya sebagai ahli waris karena ahli waris tersebut masih merupakan keturunan dan memiliki hubungan darah dengan ahli waris.

2. Mengenai harta waris berupa sebidang tanah berstatus Hak Milik dari si pewaris sudah sepatutnya secara hukum beralih kepada ahli waris baik ahli waris berwarganegara Indonesia maupun ahli waris yang telah berpindah warga negara menjadi warga negara asing. Sehingga meskipun ahli waris tersebut telah berganti warga negara menjadi warga negara asing dan masih menguasai tanah yang berstatus Hak Milik, maka tetap tidak akan menghapuskan haknya menguasai tanah yang berstatus Hak Milik yang berdasarkan ketentuan perundang-undangan yang berlaku yaitu hanya dapat menguasai tanah berstatus Hak Milik maksimal jangka waktu 1 (satu) tahun, jika melebihi dari 1 (satu) tahun maka tanah tersebut menjadi tanah negara. Adapun upaya hukum yang dapat dilakukan ahli waris warga negara asing yang masih menguasai tanah berstatus Hak Milik yaitu dengan cara menjual tanah tersebut kepada warga negara Indonesia atau mengajukan permohonan Hak Pakai kepada Badan Pertanahan Nasional sesuai dengan perundang-undangan yang berlaku. 


\section{Daftar Bacaan}

\section{Buku}

A. Pitlo, Perkembangan Hukum Waris Praktik Penyelesaian Sengketa Kewarisan Di Indonesia (Prenadamedia Grup 2019).

Adrian Sutedi, Tinjauan Hukum Pertanahan (PT Pradnya Paramita 2009).

Afndolah Novianta Tarigan, PenyidikanTerhadapWarga Negara Asing Yang Melakukan Penyalahgunaan Visa Kunjungan (Studi Di Kantor Imigrasi Kelas I Khusus Kota Medan (Universitas Muhammadiyah Sumatera Utara 2019).

Arba, Hukum Agraria Indonesia (Sinar Grafika 2016).

Boedi Harsono, Undang-Undang Pokok Agraria Sedjarah Penjusunan, Isi, Dan Pelaksanaannja (Jambatan 1971).

Effendi Perangin, Hukum Agraria Indonesia Suatu Telaah Dari Sudut Pandangan Praktisi Hukum (Rajawali 1989).

John Salindeho, Masalah Tanda Dalam Pembangunan (Sinar Grafika 1987).

Johny Ibrahim, Teori Dan Metodologi Penelitian Hukum Normatif (Bayumedia 2012).

Oemar Moechthar, Dasar-Dasar Teknik Pembuatan Akta (Airlangga University Press 2017).

Sri Hajati \& Agus Sekarmadji, Buku Ajar Politik Hukum Pertanahan (Pusat Penerbitan dan Percetakan UNAIR 2011).

Sri Winarsi et. a., Seri Hukum Agraria : Prinsip Prioritas Dalam Sistem Hukum Agraria Indonesia (Jakad Media Publishing 2021).

Supriadi, Hukum Agraria (Sinar Grafika 2007).

Urip Santoso, Hukum Agraria E Hak-Hak Atas Tanah (Kencana Prenada Media Group 2007).

- - , Hukum Agraria Kajian Komprehensif (Kencana Prenadamedia Group 2014).

- -, Pendaftaran Dan Peralihan Hak Atas Tanah (Prenadamedia Group 2019).

\section{Laman}

Tri Jata Ayu Premaesti, ‘Bolehkan Warga Negara Indonesia Berkewarganegaraan Ganda?' <https://www.hukumonline.com/klinik/detail/ulasan/cl822/ bolehkah-wni-berkewarganegaraan-ganda> accessed 26 April 2021.

How to cite: Muhammad Setya Ady Syarifuddin, 'Kedudukan Hukum dan Keabsahan Kepemilikan Hak Atas Tanah Warga Negara Asing yang Berasal Dari Pewarisan' (2021) Vol. 4 No. 3 Notaire. 